\title{
INDONESIAN COLLEGE STUDENTS' PERCEPTIONS OF TOEFL PREPARATION CLASS
}

\author{
Siti Masfufah \\ Jakarta State University \\ siti.masfufah@live.com
}

\begin{abstract}
This is the report of a pilot study of a dissertation. This study investigated what Indonesian students perceived of the TOEFL Preparation class. The researcher interviewed 11 students of Economics. The students' age ranged from 18 - 23 years old. Seven of them had a job. Three of them were planning to have a job. The other one was a full-time student. This research revealed that the majority of the students were satisfied with the TOEFL Preparation class. The teacher helped them understand English compared to their knowledge before taking the TOEFL class. However, the students suggest that the duration for each meeting should be at least 120 minutes. Beside, the teacher should provide group work activities and homework. In addition, the teacher should come to class on time. Some recommendations of the findings are discussed in this paper.
\end{abstract}

Keywords: Students' perceptions, TOEFL preparation, pilot study

\section{INTRODUCTION}

Competition in getting a job is getting harder. It is a challenge for colleges and universities to anticipate the issue. Education must be able to handle the growing of the liberalization of job market (Direktorat Jendral Pembelajaran dan Kemahasiswaan Kementerian Riset, Teknologi, dan Pendidikan Tinggi Republik Indonesia, 2015). A college of economics, Sekolah Tinggi Ilmu Ekonomi Indonesia, provides seven-semester English course--six semesters for TOEFL Preparation and one semester for general English.

The TOEFL Preparation course aims at helping students achieve TOEFL ITP (Institutional Testing Program) score of 450 as one of prerequisites of graduating from the college (Yayasan Pendidikan Fatahillah Jakarta Sekolah Tinggi Ilmu Ekonomi Indonesia website, 2017). If the students cannot achieve the score, the students may enclose the certificate of passing the six-semester TOEFL Preparation course (Sikad STEI Sekolah Tinggi Ilmu Ekonomi Indonesia, 2017). The TOEFL Preparation course had run for one year. To see 
what the students perceive, this research was conducted. This research aimed at knowing what should be maintained and what to improve based on students' perceptions.

The TOEFL test influences teachers what to teach and how to teach it (Barnes, 2016). Even the counterpart of the TOEFL that is the IELTS (International English Language Testing System) does the same thing. Both TOEFL and IELTS strongly influenced the teachers' attitude (Erfani, 2014). They also influenced the teaching learning activities in both classes (Erfani, 2012).

Students have different attitude towards the TOEFL. Stricker and Attali (2010) studied the attitude of students in China, Colombia, Egypt, and Germany. The study found that the attitude of the students was moderately positive toward the TOEFL in most countries but neutral in Germany. The attitude towards listening and speaking sections was favorable but less favorable for speaking section in every country and not favorable in Germany and Columbia.

Students' attitude influences the difficulties the students found while doing the TOEFL test. Mahmud (2014) studied the problems faced by the Indonesian students who had TOEFL-like or TOEFL prediction. The study found that the problems are low basic skills, less practice and motivation, and age as well as social status.

Some TOEFL preparation courses may help students increase their TOEFL score. Ma and Cheng (2015) studied Chinese students' perceptions towards the value of the TOEFL Preparation in a Canadian university. The study revealed three things. The first, the quality was on the teachers, instruction, and the instructional content. The second, there were benefits in the efficiency and reorientation on the TOEFL and English development. The third, there were engagement and effective achievement in learning communities and sources of motivation.

Another research was conducted by Mousavi, Arizavi, and NamdarNamdari (2014). They studied the effect of the TOEFL and IELTS preparation on students' reading achievements. The study revealed that the effect is more visible on the IELTS than on the TOEFL reading. Students 
taking IELTS preparation could perform better significantly on the IELTS reading test.

What researchers have studied in the area of TOEFL Preparation program is varied. Some researchers compared the effect of TOEFL Preparation and its counterpart that is the IELTS to teachers' and students' attitude, the way of teaching influenced by both English language tests and the test section like reading section. Some other researchers investigated the valuable things of the TOEFL Preparation. The researchers studied the TOEFL iBT. However, Mahmud (2014) studied the TOEFL ITP-like or TOEFL prediction.

This research studied the TOEFL preparation for preparing the TOEFL ITP-an institutional TOEFL conducted by English-language centers, universities, or other institutions (Rogers, 2011)-test that consists of three sections: listening, structure and written expression, and reading comprehension. This research focused on what students perceived of the TOEFL Preparation class they were taking. The findings will contribute practically, institutionally, and scholarly.

This research is a qualitative study. It gathered data through a structured interview (see the list of the questions in Appendix). Researcher used content and thematic analysis. The participants of this research were 11 first-semester students out of 108 students joining the TOEFL Preparation course. Researcher asked some students who had the lowest score of TOEFL ITP-practice pretest (adopted from Practice Test A of "TOEFL ITP Assessment Series: Practice Tests" book, 2010) for having an interview about their perceptions of studying English in the TOEFL Preparation course. The researcher provided 100 minutes to interview the students. The duration had 11 students interviewed. Their age ranged from 18 to 23 years old. They were ten female and one male student. Five students had a part-time job and the other did not.

The researcher called the students one by one if they were able to have an interview with the researcher. The interview was recorded by a cell phone audio recorder. If the student disagreed, the researcher did not record it. However, the researcher displayed a Google form to record the students' 
responses. The students were allowed to see what was written by the researcher on the Google form so that if there was any misinterpretation, the students were able to clarify it. After the interview was done, the responses were submitted to the internet (Google Drive).

\section{DISCUSSION}

\section{Motivations of Taking TOEFL Preparation Class}

TOEFL Preparation is an additional course. The grade is not listed in the GPA (Grade Point Average) transcript. Unlike other courses which students must pay for, the TOEFL Preparation course is free of charge. Therefore, the first question delivered to the students was what motivated them to take the course. The following chart shows the result.

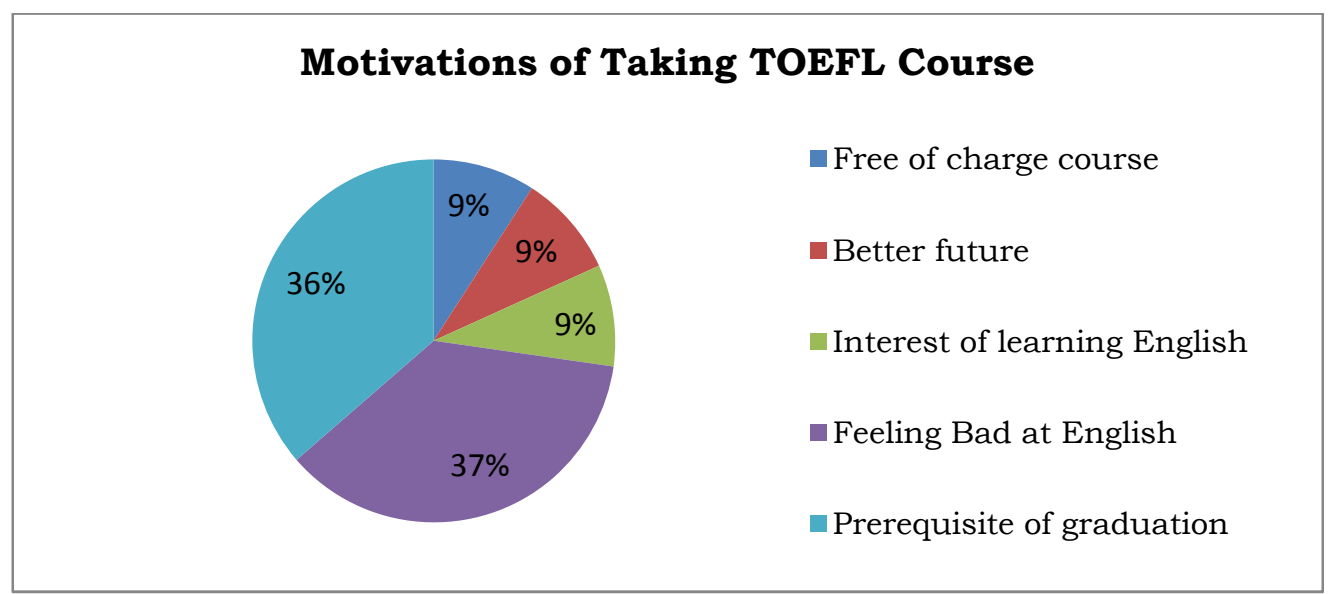

Figure 1. Motivations of Taking TOEFL Course

Researcher found five different answers. One student took the course because the course is free of charge. Another student said it was because of the future the student would have. The other student conveyed the reason of taking the course was due to the interest of learning English. Four students found themselves bad at English so that they wanted to be to understand and master English and the other four students took the course due to the prerequisite of graduating from the college. 
Impressions of Learning English in TOEFL Preparation Class

The students had had 4 meetings of the TOEFL Preparation class. They had pretest in the first meeting, learning listening skill in the second meeting, learning structure skill in the third meeting, and reading skill in the fourth. One student said that the listening section was too fast and not clear. Two students conveyed that the duration of each meeting was not enough. It needs longer time at least two hours. The student said English is not Mathematics. English has to be explained clearly because English in Indonesia is not an ESL (English as a Second Language) which means English cannot be found in any institutions. Therefore, duration of learning English in classroom should be longer.

The rest of the students (73\%) found that learning English in TOEFL Preparation class is happy, fun, positive, and interesting. The reasons are they became to understand English better. They compared how the learned English in schools. They said, in senior high school, teachers fed them; in campus, they were encouraged to think by themselves. Another student said that when she was in senior high school, the teachers did not focus on teaching. They tended to make humor in class and gave students tasks and materials to be memorized. The teachers seldom focused on materials. Similar to the previous student, another student said that in senior high school, the teachers tended to give exercises and seldom explained the materials.

Another different student said that this way of teaching (in college) should have been given before they had Ujian Nasional, an exam conducted nationally for schools from elementary to senior high schools and the questions were designed, made, and distributed by the government. She found herself understand English late that is in campus not in schools. The other student said that when she was in senior high school, she did not know how to make sentences in English. She did not know about verbs and tenses. Even though their comprehension of English improved, one student said that she had problem with English vocabulary. Consulting to Google Translate made her more confused. 
Students' Perceptions about Structure Section

The mean of the structure section score was the lowest of all the TOEFL sections in five classes taught by the researcher. See table 1 below.

Table 1. Mean of TOEFL Pretest Score

\begin{tabular}{llllll}
\hline Section & Class A & Class B & Class C & Class D & Class E \\
\hline Listening & 36.00 & 36.89 & 37.40 & 39.32 & 37.33 \\
\hline Structure & 34.16 & 34.00 & 36.93 & 38.52 & 35.14 \\
\hline Reading & 38.08 & 35.32 & 38.87 & 40.68 & 37.44 \\
\hline
\end{tabular}

Note: scoring uses TOEFL ITP conversion

Because of the data in the table, the researcher asked students' perceptions of the issue. Nine out of 11 (82\%) students said that they did not know the structure of English sentences so that they could not determine which is correct and which is incorrect. They did not know which subject, verb, and adverb are. They also did not know the meaning most of the vocabulary they found $\mathrm{n}$ the questions. Other two students said there are too many questions but the duration is short. The other student said she had problem with the translation of the vocabulary.

As the interview was conducted in the fifth meeting, the teacherresearcher asked if she had helped them understand materials well. Eight students found that their teacher helped them understand materials even though one student said she was still confused. Another student said that his teacher had been doing very well in helping him understand materials. Another student said she still did not understand the materials, and the other student was absent when the class had structure-section materials.

To prove if the students really understand what their teacher explained, the teacher-researcher tested the students. The researcher asked the students to read the previous materials then asked them to decide if the sentences are correct or incorrect. The previous materials were subject-verb agreement. Two out of ten students--one student was absent-could answer correctly. The rest still failed to determine which is subject, which is the main verb, and therefore 
they failed to determine if the sentences are correct or incorrect. They mistook noun as a verb and verb as a noun, e.g. mistaking the word "assigned" as a subject.

Complains Related to the TOEFL Class

One of objectives of this research is to know what to improve in the TOEFL Preparation program. Researcher asked students what they complained about the TOEFL-preparation class. Four students were satisfied about the course. They had no any complains about the TOEFL class. Two students complained about the duration of each meeting. They found that the duration was too short so that the teacher could only explain a little and the students lacked time to do the exercise.

One student complained about herself that she could understand the materials when the teacher was explaining them, but she was stuck when she was doing exercise. Another student had problem with her own schedule: there was the schedule of the TOEFL and the schedule of another course after the TOEFL. She found that the schedule of the TOEFL was too close to prayer time. Another student said that her problem is on the structure section. The other student complained about the teacher who often came late to class.

Improvements to be made

The researcher asked the students what to improve to help them understand materials better. One student said that the teacher had already been perfect. What to add is the duration. The duration should be at least 120 minutes. The other three students also mentioned about adding the duration. Three students mentioned that the number of exercise should be more. Three students said that the students should reread materials at home by themselves. Another student said that there should be homework and group work.

This research found that the students had different motivations of taking the TOEFL Preparation class. Passing the six-semester TOEFL Preparation course as the alternative solution if the students did not achieve the TOEFL ITP score of 450 became one of motivations students had. Beside 
this motivation, another external motivation was the course was free of charge. The students took the advantage of the financial side as taking TOEFL Preparation course out of campus is mostly expensive. In addition, the students had some internal motivations, such as their lack of English knowledge, interest of learning English, and future. Interest of learning English and future that become students' motivations to learn English are also found in the previous research conducted by Redondo and Martin (2015). Long, Ming, and Chen (2013) state that students' interest has important role in language learning.

Students' motivations of taking the TOEFL Preparation course ideally should meet the satisfactions of learning English in the TOEFL Preparation class. Indeed, the TOEFL Preparation gave satisfactions to them. They found that the TOEFL Preparation class made helped understand English. It made them see the class was fun, happy, positive, and interesting. They found that the way the teacher taught them-encouraging students to think by themselves-should have been applied in senior high schools.

They complained about their senior-high school teachers who tended to make humors, giving task and exercises as well as materials to memorize instead of teaching and explaining English materials. In fact, encouraging students to own self initiative is one of the characteristics of an ideal highschool teacher (Ciascai \& Vlad, 2014). Beside, teacher's role seems to be the most directly affect students' motivation (Redondo and Martin, 2015) and motivation positively influences students' success in English learning (Al Othman \& Shuqair, 2013).

The fact that the students had lack of English knowledge was admitted by $82 \%$ of the participants. They said they did not know the structure of English sentences. They did not know how to make sentences in English. This is the main reason why their structure and written expression section of the TOEFL score was the lowest. It is supported by the research finding revealed by Redondo and Martin (2015) that more than a half of their participants found that grammar is the most difficult of English.

To prove that the students did understand the English structure materials after being taught by the teacher, the teacher-researcher tested 
them with the same materials of the previous meeting. Twenty percent of the students did excellently and the other $80 \%$ still made mistakes. As it was the first time learning English structure, it was normal that they still made mistakes as Shanks and the Staff of KAPLAN (2004) stated that the students have to be familiar with the TOEFL test. When asked what made the students still make mistakes, they answered that they needed more time to practice. It should be at least two hours (120 minutes) per meeting, not 100 minutes. A hundred minutes is only enough for a little explaining materials and examples of exercises done by the teacher and a little time for students to do the exercises from the teacher. According to the study conducted by ETS-the owner of the TOEFL-to increase 40 points of the TOEFL score, test takers should approximately take 300-hour intensive English program (Shanks $\&$ the Staff of KAPLAN, 2004).

Duration also should be considered by the teacher as one student complained about the teacher who often came late. However, this complains was contrast with another student saying that the schedule of the class was too close to time prayer. The reason of the teacher coming late was giving the students ten minutes to take lunch and prayer as the time of the previous class ended at 12:10 p.m. and the start of the following class was at 12:30 p.m. Hence, the students only had 20 minutes for break (lunch and praying as most of the students were Muslims). However, lateness causes disorganization, distraction, problems in reaching goals, and the failure of life (Dafiaghor, 2011). Thus, the teacher should change herself to be always on time to prevent disorganization and distraction related to effectiveness of teaching instructions and students' goals of learning English in the TOEFL Preparation program.

The next aspect the teacher should improve is providing group work activities and homework as one student asked for. It supports another student's statement saying that she could understand when the teacher was explaining the materials but was stuck when she was doing the exercises. The other student said that student themselves should reread materials at home to improve their achievement. Group work activities are necessary as Masfufah (2016) revealed that working in small groups can help students understand 
materials more easily because the students share their knowledge to each other. It is hoped that homework will help the students reread materials when they are at home even though the study conducted by Maharaj-Sharma and Sharma (2016) revealed that most students in science classroom felt that homework was unnecessary.

\section{CONCLUSION}

This research found five important findings. The first, students' motivations of taking the TOEFL class were certificate of passing the sixsemester TOEFL Preparation as the alternative of the TOEFL ITP score of 450, the awareness of having low skill in English, interest of learning English, a better future, and the free of charge course. The second, majority of the students were satisfied with how the teacher taught them. However, changing duration from 100 to become at least 120 minutes per meeting is needed. The third, most of the students did not know the structure of English. The fourth, even though the students perceived their teacher helped them understand materials, they still made mistakes when asked about the answers of materials that had been given and discussed in the previous meeting. The fifth, the improvements should be made are the students should be able to manage their time and reread materials at home, the teacher should provide group work activities, homework, and come on time, as well as the college should add the duration become 120 minutes each meeting.

Regarding to the findings, the researcher makes some suggestions. First, because many students joined the course due to their own motivations, the teachers and college should make them satisfied learning English in the TOEFL Preparation program. Second, since most students did not know the structure of English, the teachers should teach them very basic English. Third, the teachers should give students more practice as they understood what teacher explained but were stuck when they were doing the exercises. 


\section{REFERENCES}

Al Othman, F.H.M., \& Shuqair, Khaled M. (2013). The impact of motivation on English language learning in the Gulf States. International Journal of Higher Education, 2(4), 123-130. Retrieved from http://www.sciedu.ca/journal/index.php/ijhe

Barnes, M. (2016). The washback of the TOEFL iBT in Vietnam. Australian Journal of Teacher Education, 41(7), 18-174. Retrieved from htt://ro.ecu.edu.au/ajte/vol41/iss7/10

Ciascai, L., \& Vlad, I. (2014). Perception of school and university students of ideal teacher behaviours (ii): Pilot study. Acta Didactica Napocensia, 7(3), 49-58. Retrieved from https://eric.ed.gov/?id=EJ1053277

Dafiaghor, K.F. (2011). Lateness: A major problem confronting school administrators in Delta State, Nigeria. International NGO Journal, 6(7), 166-169. doi:10.5897/NGOJ11.011.

Direktorat Jendral Pembelajaran dan Kemahasiswaan Kementerian Riset, Teknologi, dan Pendidikan Tinggi Republik Indonesia. (2015). Kerangka kualifikasi nasional indonesia. Retrieved from http://kknikemenristekdikti.org/asset/pdf/001-dokumen_kkni.pdf

Educational Testing Service. (2010). TOEFL ITP Assessment Series: Practice Tests Volume 1. Jakarta, Indonesia: Erlangga.

Erfani, S. S. (2012). A comparative washback study of IELTS and TOEFL iBT on teaching and learning activities in preparation courses in the Iranian context. English Language Teaching, 5(8), 185-195. doi:10.5539/elt.v5n8p185.

Erfani, S. S. (2014). An investigation on the attitudes of IELTS and TOEFL iBT teachers: A quantitative and qualitative washback study. British Journal of Education, Society \& Behavioural Science, 4(1): 88-102. Retrieved from http://www.journalrepository.org/media/journals/BJESBS_21/2013/O ct/Erfani412013BJESBS5674_1.pdf

Long, Chunmei., Ming, Zhu., \& Chen, Liping. (2013). The study of student motivation on English learning in junior middle school -- a case study of no.5 middle school in Gejiu. English Language Teaching, 6(9), 136-145. doi:10.5539/elt.v6n9p136. 
Masfufah, Indonesian College Students' Perceptions of TOEFL Preparation Class

Ma, J., \& Cheng, L. (2015). Chinese students' perceptions of the value of test preparation courses for the TOEFL iBT: Merit, worth, and signifiance. TESL Canada Journal/Revue TESL Du Canada, 33(1), 58-79. Retrieved from

http://www.teslcanadajournal.ca/index.php/tesl/article/view/1227

Maharaj-Sharma, R., \& Sharma, A. (2016). What students say about homework - Views from a secondary school science classroom in Trinidad and Tobago. Australian Journal of Teacher Education, 41 (7), 146-157. Retrieved from http://ro.ecu.edu.au/ajte/vol41/iss7/9

Mahmud, M. (2014). The EFL students' problems in answering the Test of English as a Foreign Language (TOEFL): A study in Indonesian context. Theory and Practice in Language Studies, 4(12), 2581-2587. doi:10.4304/tpls.4.12.2581-2587.

Masfufah, S. (2016, November). Getting students actively involved in classroom discussion through text-based $C M C$. Paper presented at The $2^{\text {nd }}$ International Multidisciplinary Conference in Jakarta, Indonesia.

Mousavi, S. A., Arizavi, S., \& Namdari, N. (2014). The effect of test preparation on the test performance the case of the IELTS and TOEFL iBT reading tests. International Journal of English and Education, 3(2), 10-22. Retrieved

from http://ijee.org/yahoo_site_admin/assets/docs/2.83201219.pdf

Redondo, R.E., \& Martín, J.L.O. (2015). Motivation: The road to successful learning. PROFILE, 17(2), 125-136. Retrieved from http://dx.doi.org/10.15446/profie.v17n2.50563

Rogers, B. (2011). The complete guide to the TOEFL test: PBT Edition. Boston: Heinle Cengage Learning

Shanks, J., \& the Staff of KAPLAN. (2004). KAPLAN TOEFL Paper-and-Pencil (3rd ed). New York: Simon \& Schuster.

Sikad STEI Sekolah Tinggi Ilmu Ekonomi Indonesi. (2017, April 30). Berita dan Pengumuman. Retrieved from http:// sikad.stei.ac.id/index.php?pilihan=berita\&aksi=detil\&id=13

Stricker, L. J., \& Attali, Y. (2010). Test takers' attitudes about the TOEFL iBT. TOEFL iBT Research Report. Retrieved from https://www.ets.org/Media/Research/pdf/RR-10-02.pdf 


\section{EduLite}

Journal of English Education, Literature, and Culture

Volume 3, Number 1, February 2018

Yayasan Pendidikan Fatahillah Jakarta Sekolah Tinggi Ilmu Ekonomi Indonesia, (2017, April 30). Program Studi S-1 Manajemen Sekolah Tinggi Ilmu Ekonomi Indonesia (STEI).Retrieved from http:/ / stei.ac.id/registrasi/index.php/2014-05-09-08-57-23/2014-0509-08-13-03/99-syarat-pendaftaran/94-program-studi-s-1-manajemensekolah-tinggi-ilmu-ekonomi-indonesia-stei. 